\title{
Stature in adults as an indicator of socioeconomic inequalities in Mexico
}

\author{
Lilia V. Castro-Porras, ${ }^{1}$ Mario E. Rojas-Russell, ${ }^{2}$ Ángeles Aedo-Santos, ${ }^{1}$ Emma G. \\ Wynne-Bannister, ${ }^{1}$ and Malaquías López-Cervantes ${ }^{1}$
}

Suggested citation

Castro-Porras LV, Rojas-Russell ME, Aedo-Santos A, Wynne-Bannister EG, López-Cervantes M. Stature in adults as an indicator of socioeconomic inequalities in Mexico. Rev Panam Salud Publica. 2018;42:e29. https://doi.org/10.26633/RPSP.2018.29

\begin{abstract}
Objective. To estimate the association between stature in Mexican adults and some sociodemographic factors.

Methods. We studied a sample of 30970 subjects, using anthropometric data from the 2012 National Health and Nutrition Survey (ENSANUT 2012). The first quartile was used as the cutoff to define short stature. We analyzed differences among stature strata for sociodemographic variables by using the Kruskal-Wallis test. We estimated odds ratios to measure the association between stature and sociodemographic variables, controlling for potential confounders.

Results. Persons from the southern region of the country were some three times as likely to be of short stature than were subjects in the northern region. The stature difference between the Mexican states with the highest and the lowest average stature was larger than the average difference in stature between Mexico and the United States of America. Adults who had had less than six years of schooling presented the highest prevalence of short stature, regardless of sex, region of the country, place of residence (rural or urban), or the proportion of indigenous language speakers in a state. In addition, the stratum with the highest marginalization (percentage of the population lacking education and services, with a low income, and living in a small community) showed the highest prevalence of short stature.

Conclusion. In Mexico, adults who are of short stature have unequal living conditions when compared to those of average or high stature, and this could drive increases in health inequity.
\end{abstract}

Keywords Socioeconomic factors; body height; adult; indigenous population; Mexico.

Stature reached at adulthood is a useful biological measure to estimate some factors related to long-term health and well-being of a population (1). Adult stature results from a combination of multiple factors, notably including genetics, age, weight at birth, nutrition at

\footnotetext{
Facultad de Medicina, Universidad Nacional Autónoma de México, Ciudad de México, México. Send correspondence to Malaquías LópezCervantes at mlopezcervantes@unam.mx

2 Facultad de Estudios Superiores Zaragoza, Universidad Nacional Autónoma de México, Ciudad de México, México.
}

an early age, physical activity, diseases contracted during life, social and economic conditions, gender-related circumstances, and the environment (2-7).

In Mexico, stature in adults has been studied, but with different aims and different cutoffs. For example, VargasAncona in 1994 (8) and Lopez-Alvarenga in 2004 (9) researched the prevalence of individuals with short stature (SS). The Vargas-Ancona study reported a prevalence of SS of $76 \%$ for women $\leq 151 \mathrm{~cm}$ and of $58 \%$ for men $\leq 164 \mathrm{~cm}$ for individuals from Yucatan, a state in southern Mexico.

In contrast, Lopez-Alvarenga found an overall SS prevalence of $20.7 \%$ (women $\leq 150 \mathrm{~cm}$ and men $\leq 160 \mathrm{~cm}$ ), with a higher prevalence in women than in men $(25.8 \%$ vs. $13.6 \%)$, in six Mexican cities in the center and north of the country. The same SS cutoffs as those of the LopezAlvarenga research were applied in a study about the ability of body mass index (BMI) to detect obesity-associated morbidity in subjects with a normal or 
short stature (10). In addition, those same cutoffs are still used in the Official Mexican Standard (Norma Oficial Mexicana) to define SS in adults (11).

There is no internationally accepted criterion to define SS in adults. Some authors have used the $3^{\text {rd }}, 5^{\text {th }}$ or $10^{\text {th }}$ percentile $(5,12-14)$, and others have used a fixed number to establish cutoffs $(9,10)$. The first quartile (Q1) has also been used as cutoff for short stature (4, 15-20).

In countries with an indigenous population, such as Mexico, being indigenous should be analyzed to avoid confounding with short stature. Most of the indigenous population are below the national average stature. According to Mexico's 2015 Intercensal Survey, the country had an estimated 7.4 million indigenous people (including 3.8 million women), representing $7 \%$ of the population aged 3 years and older (21).

In regards to socioeconomic factors, some authors have found an association between SS and low socioeconomic status, as measured by family income (3) and education level achieved and type of employment (22). These associations have continued even though average height has increased in recent decades (23).

Using data from the early and late twentieth century, Schick and Steckel (24) found that taller individuals and populations earn more money than their shorter counterparts. This result is due, in large part, to a strong correlation between adult height and accumulating human capital. Furthermore, they attribute this outcome to the significant association between adult height and both cognitive and noncognitive abilities.

In Mexico, little is known regarding the social inequalities related to stature. Therefore, the objective of this population-based study was to estimate the association between stature in Mexican adults and some sociodemographic factors.

\section{MATERIAL AND METHODS}

To relate stature in adults with sociodemographic variables, we used data from the 2012 National Health and Nutrition Survey (ENSANUT 2012), a population-based survey that was conducted in Mexico by the Health Ministry. Because most of the indigenous population have a stature below the national average, we used data from the 2015 Intercensal Survey (21) to analyze the indigenous population (people who speak an indigenous language) as a potential confounder. Detailed descriptions of the design and coverage of the two surveys are available $(25,26)$.

\section{Statistical analysis}

We used statures equal or below the $25^{\text {th }}$ percentile (Q1) as the criterion for short stature.

Percentages for each variable were analyzed by quartile and sex. We generated a variable for the prevalence of indigenous language speakers for each state of the country. The sample was divided into quartiles by the prevalence of indigenous language speakers. We estimated the cutoff value for indigenous population from Q4 $\left(75^{\text {th }}\right.$ percentile) of prevalence of indigenous language speakers.

The following variables with their respective categories were considered from the ENSANUT 2012 data: geographic region, locality, socioeconomic status (SES) (27), years of schooling, marginalization (percentage of the population lacking education and services, with a low income, and living in a small community), and, BMI (weight in $\mathrm{kg} /$ height in $\mathrm{m}^{2}$ ). For the BMI, we applied the internationally established categories of underweight, normal weight, overweight, and obesity, based on the cutoffs set by the World Health Organization (WHO): $<18.5 \mathrm{~kg} / \mathrm{m}^{2}$ (underweight); 18.5 to 24.9 $\mathrm{kg} / \mathrm{m}^{2}$ (normal weight); 25.0 to $29.9 \mathrm{~kg} /$ $\mathrm{m}^{2}$ (overweight); and $\geq 30.0 \mathrm{~kg} / \mathrm{m}^{2}$ (obesity).

We described the data by quartiles according to the relative frequency distribution. We then performed the Kruskal-Wallis test to analyze differences, as well as the chi-squared test of homogeneity of odds ratio (OR) and the test for linear trend of the log odds to analyze the prevalence of SS for each category of variables and the trend in this association. Confounding and interaction analyses by indigenous condition were performed using the MantelHaenszel odds ratio test $\left(\mathrm{OR}_{\mathrm{M}-\mathrm{H}}\right)$.

The OR for SS was calculated for the categories of schooling variable using the $\mathrm{OR}_{\mathrm{M}-\mathrm{H}}$ test, controlling by sex, region, place of residence (rural or urban), and indigenous condition. ORs were calculated for each state, and the mean of prevalence was used as reference in order to show Mexican states below and above the mean.
Average stature and prevalence of SS was described according to the distribution of the relative frequency by state, both for the total sample and for each sex. The SS distribution was presented in a map, for assessment. All analyses were performed using the Stata 13.0 software (StataCorp, College Station, Texas, United States). The critical $p$ value was set at $<0.05$.

\section{Ethics and consent to participate}

The ENSANUT 2012 procedures were reviewed and approved by the ethics, research, and biosecurity committees of the National Institute of Public Health of Mexico, in particular with regard to confidentiality and nondisclosure of information. For each instrument and population group, a consent form that specified that the subjects were informed and participating voluntarily was issued by the National Institute of Public Health of Mexico.

\section{RESULTS}

We considered 31000 subjects with complete data and who were aged 20 to 59. We excluded 30 cases for having a stature under $130 \mathrm{~cm}$ or over $200 \mathrm{~cm}$. The final sample had 30970 subjects, of whom 18331 (59.2\%) were women.

Regarding stature, the following groups were established for women: $\leq$ $148.5 \mathrm{~cm}$ (Q1), 148.6 to $153.1 \mathrm{~cm}$ (Q2), 153.2 to $157.8 \mathrm{~cm}$ (Q3), and $\geq 157.9 \mathrm{~cm}$ (Q4). For men, the following groups were formed: $\leq 161.1 \mathrm{~cm}$ (Q1), 161.2 to 166.0 $\mathrm{cm}$ (Q2), 166.1 to $171.0 \mathrm{~cm}$ (Q3), and $\geq$ $171.1 \mathrm{~cm}(\mathrm{Q} 4)$. For both women and men, the lowest quartile (Q1) was considered as the cutoff point to determine SS.

Four categories were established for indigenous language prevalence by state: $\leq$ $1.4 \%$ (Q1); $1.5 \%$ to $2.7 \%(\mathrm{Q} 2) ; 2.8 \%$ to $11.2 \%$ (Q3); and $\geq 11.3 \%$ (Q4). Indigenous population was defined as falling into Q4.

Table 1 shows the percentages of the population by quartile and socioeconomic factors for the total population and by sex. For example, for the first category of the age factor for women (20 to 29 years), $18.6 \%$ of women in that age group were in Q1, 21.9\% in Q2, 25.9\% in Q3, and $33.6 \%$ in Q4. Given that the lowest quartile (Q1) was considered as the cutoff point to determine SS, we can say that for the first age category for women, $18.6 \%$ of them were of short stature. In contrast, 


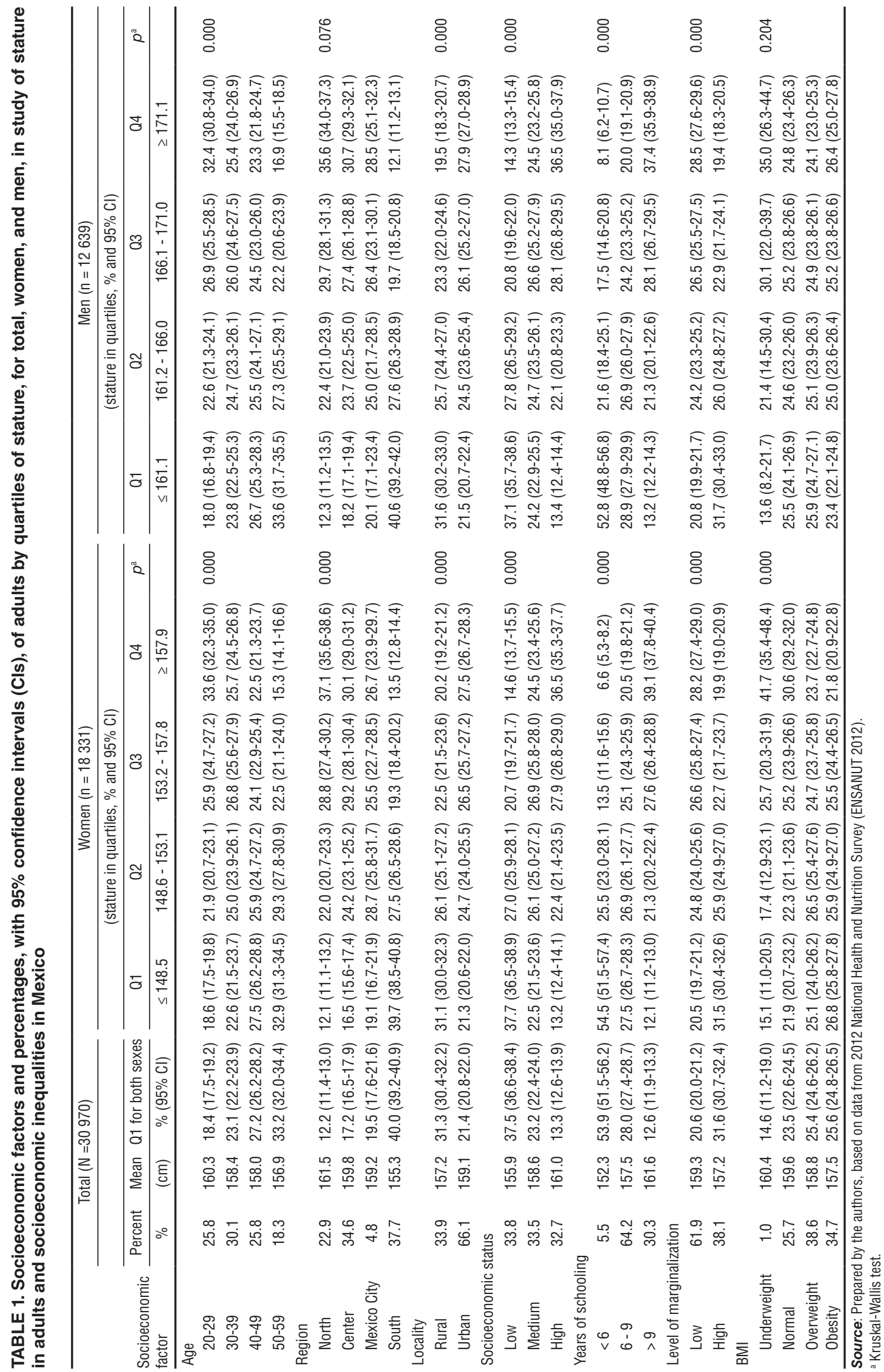


for the last age category (50 to 59 years), $32.9 \%$ of women in that age group were in Q1, 29.3\% in Q2, 22.5\% in Q3, and $15.3 \%$ in $\mathrm{Q} 4$. Thus we can say that $32.9 \%$ of women from 50 to 59 years old had SS.

\section{Age}

When we compared the age groups, we found that the group aged 50 to 59 was almost two times as likely to have SS as the group aged 20 to 29 (OR 2.2; 95\% confidence interval $(\mathrm{CI})=2 \cdot 0-2.4)$. The prevalence of SS by age group had a positive trend. When we controlled for indigenous status, we found a $32 \%$ higher probability of having SS for each increase in the age group category $\left(\mathrm{OR}_{\text {adjusted }} 1.32\right.$; $95 \% \mathrm{CI}=1.29-1.36)$.

\section{Regions}

In the analysis by regions, we found that the southern region had the highest prevalence of SS for both sexes combined ( $40.0 \%, 95 \% \mathrm{CI}=39.2 \%-40.9 \%)$. This represents a difference greater than 25 percentage points when compared to the northern region $(12.2 \%, 95 \% \mathrm{CI}=11.4 \%$ $13.0 \%$ ). When we calculated the adjusted odds ratio with the indigenous component, the subjects from the southern region had nearly three times the odds of having SS in comparison to those in the northern region $\left(\mathrm{OR}_{\text {adjusted }} 3.1 ; 95 \% \mathrm{CI}=\right.$ 2.8-3.5), and two times that of the center region $\left(\mathrm{OR}_{\text {adjusted }} 2.1 ; 95 \% \mathrm{CI}=1.9-2.3\right)$.

\section{Locality}

When comparing by locality, almost one-third of the inhabitants of rural areas have SS $(31.3 \%, 95 \% \mathrm{CI}=30.4 \%-32.2 \%)$, in contrast to just one-fifth of the inhabitants of urban areas $(21.4 \%, 95 \% \mathrm{CI}=$ $21.3 \%-21.5 \%$ ).

\section{Socioeconomic status}

By socioeconomic status, the highest prevalence of SS for both sexes was found in those with low SES (37.5\%, 95\% $\mathrm{CI}=36.6 \%-38.4 \%$ ), while in those with high SES it was lower than $14 \%(13.3 \%$, $95 \% \mathrm{CI}=12.6 \%-13.9 \%)$. There was a negative trend between SES and the prevalence of SS.

When the data were adjusted for the indigenous component, subjects with the lowest socioeconomic status had some three times the odds of having SS than did those with the highest socioeconomic status (OR $\left.{ }_{\text {adjusted }} 3.1 ; 95 \% \mathrm{CI}=2.9-3.5\right)$, and $77 \%$ more probability in relation to those in the middle socioeconomic status $\left(\mathrm{OR}_{\text {adjusted }} 1.77 ; 95 \% \mathrm{CI}=1.63-1.92\right)$. No interaction was observed when the analysis of socioeconomic status was adjusted for the indigenous component ( $p=0.329$ ).

\section{Schooling}

In regards to schooling, the prevalence of SS among adults who had less than six years of schooling was higher than $50 \%$ for both sexes: $54.5 \%$ (95\% CI $=51.5 \%$ $57.4 \%)$ in women and $52.8 \%(95 \% \mathrm{CI}=$ $48.8 \%-56.8 \%$ ) in men. This contrasts sharply with the prevalence for the group that had more than nine years of schooling, whose prevalence for both sexes was lower than 14\%: $12.1 \%$ (95\% CI $=11.2 \%-13.0 \%$ ) in women and $13.2 \%$ $(95 \% \mathrm{CI}=12.2 \%-14.3 \%)$ in men.
We found a negative trend between the prevalence of SS and years of schooling. When controlling for the indigenous component, no interaction ( $p=0.48$ ) or confounding ( $\mathrm{OR}$ crude 0.38 ; $95 \%$ CI $=0.36-0.40$ vs. OR crude 0.40 ; $95 \%$ CI $=0.38-0.42$ ) was found. The odds of having SS were more than six times as high among subjects who had less than six years of schooling as compared to the odds for those who had more than nine years of schooling $\left(\mathrm{OR}_{\text {adjusted }} 6.8 ; 95 \% \mathrm{CI}=5.8-8.0\right)$, and almost three times as high as for those who had from six to nine years of schooling ( $\left.\mathrm{OR}{ }_{\text {adjusted }} 2.6 ; 95 \% \mathrm{CI}=2.3-3.0\right)$. Of the total sample, $64 \%(95 \% \mathrm{CI}=$ $63.7 \%-64.7 \%$ ) reported having from six to nine years of schooling, and only $5.5 \%(95 \%$ CI $=5.2 \%-5.7 \%)$ had less than six years of schooling.

When we used -2 standard deviations (SDs) and the $5^{\text {th }}$ percentile as cutoffs, the trend of the above results was not modified.

We found that adults who had less than six years of schooling presented the highest prevalence of SS, regardless of sex, region of the country, place of residence (rural or urban), or the prevalence of indigenous language speakers in the state (Figure 1).

\section{Level of marginalization}

In the stratum with the highest marginalization, the prevalence of SS for both sexes combined was $31.6 \%(95 \%$ $\mathrm{CI}=30.7 \%-32.4 \%)$. In comparison to the low-marginalization stratum $(20.6 \%$, $95 \% \mathrm{CI}=20.0 \%-21.2 \%$ ), there was a difference of 11 percentage points.

FIGURE 1. Prevalence of short stature in Mexican adults, by categories of years of schooling in men and women, adjusted for region and residence, in study of stature in adults and socioeconomic inequalities in Mexico $^{\mathrm{a}}$
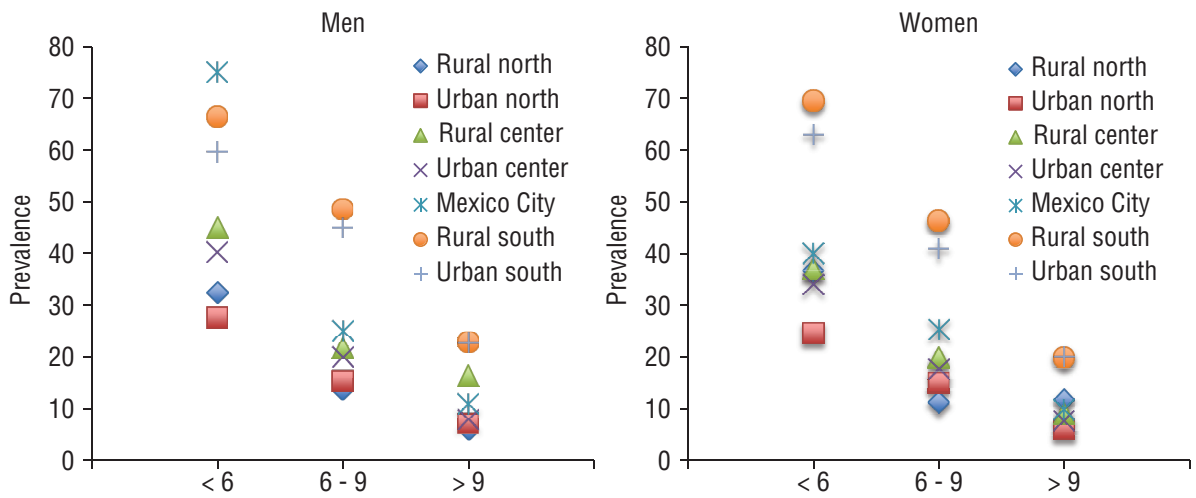

Source: ${ }^{a}$ Prepared by the authors based on data from 2012 National Health and Nutrition Survey (ENSANUT 2012). 


\section{Body mass index}

In the analysis of SS in relation to BMI categories, no interaction was found with the indigenous component $(p=0.40)$, but one was found for sex $(p<0.01)$. For the female group, the highest prevalence of SS was found in the obesity category $(26.8 \%, 95 \% \mathrm{CI}=25.8 \%$ $27.8 \%$ ), followed by the overweight category $(25.1 \%, 95 \% \mathrm{CI}=24.0 \%-26.2 \%)$. For men, the highest prevalence of adults with SS was found in the overweight category $(25.9 \%, 95 \% \mathrm{CI}=24.7 \%-27.1 \%)$, followed by the normal weight category ( $25.5 \%, 95 \%$ CI $=24.1 \%-26.9 \%)$. The sum of SS prevalences in the overweight and obesity categories was 50\% for the total sample.

In both sexes, there were no statistically significant differences between BMI categories when analyzed by age group, locality, SES, schooling, and marginalization. We did not find significant difference by geographic region for the male group.

\section{Prevalence of short stature}

The prevalence of SS was calculated for each state of the country (Additional File 1). We found that some states had a prevalence of SS for both sexes combined that was higher than $40 \%$. This is the case with Campeche $(42.8 \%, 95 \% \mathrm{CI}=$ $40.0 \%-45.7 \%)$, Quintana Roo (44.1\%, 95\% $\mathrm{CI}=41.1 \%-47.2 \%)$, Chiapas $(48.4 \%, 95 \%$ $\mathrm{CI}=45.5 \%-51.3 \%)$, Oaxaca $(48.7 \%, 95 \%$ $\mathrm{CI}=45.8 \%-51.7 \%)$, and Yucatan $(58.6 \%$, $95 \% \mathrm{CI}=55.7 \%-61.6 \%$ ). In contrast, we found that some states had a prevalence of SS lower than $10 \%$, such as Sonora
$(7.0 \%, 95 \%$ CI $=5.5 \%-8.9 \%)$, Sinaloa (7.5\%, 95\% CI $=5.9 \%-9.7 \%)$, and Durango $(8.9 \%, 95 \%$ CI $=7.1 \%-11.0 \%)$. When we analyzed by state and sex, we found similar results. However, two more groups of SS prevalence lower than $10 \%$ were found: women from Baja California Sur $(9.5 \%, 95 \%$ CI $=7.0 \%-12.9 \%)$ and men from Chihuahua $(9.3 \%, 95 \% \mathrm{CI}$ $=6.9 \%-12.4 \%$ ).

When we compared, state by state, the average prevalence of SS for the sexes combined versus the overall average SS prevalence for Mexico, we found that the states of Campeche, Quintana Roo, Chiapas, and Oaxaca had more than two times the odds of having SS, and for Yucatan, it was more than four times. In contrast, Sonora and Sinaloa had odds that were one-quarter the national average (Figure 2).

FIGURE 2. Odds ratio, with 95\% confidence interval, for short stature in adults in Mexico City and the states of Mexico, using the national mean as a reference category, in study of stature in adults and socioeconomic inequalities in Mexico

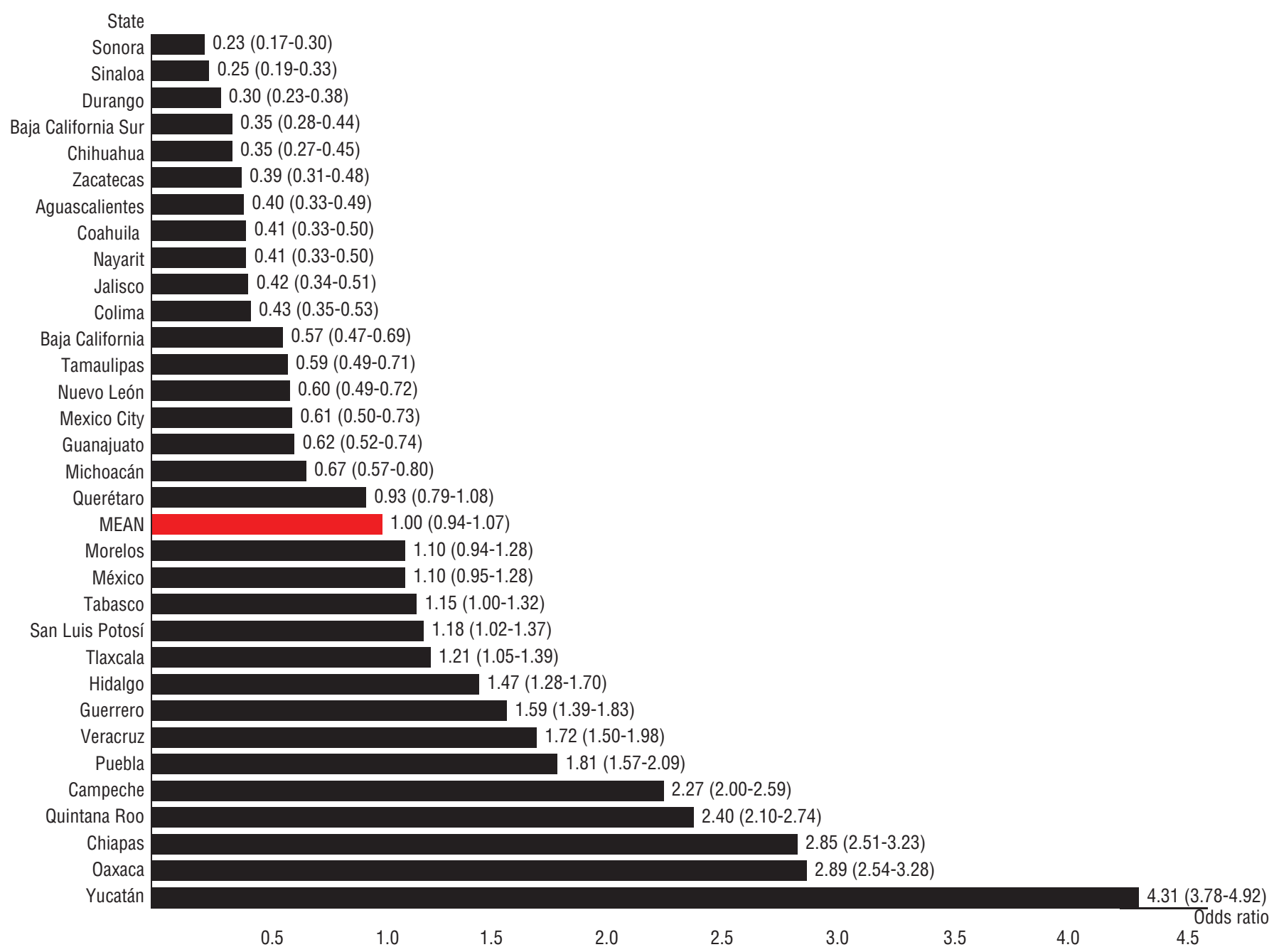

Source: Prepared by the authors based on data from 2012 National Health and Nutrition Survey (ENSANUT 2012). 
Another result from this study was the determination of the average stature by sex and state. Surprisingly, the states with the highest and lowest average stature (Sonora and Yucatan, respectively), showed a difference of $9.8 \mathrm{~cm}$ among women and of $11 \mathrm{~cm}$ among men for this variable. Those differences are wider than the ones for the average stature in Mexico versus those for developed countries such as the United States: $9 \mathrm{~cm}$ for women and $10.2 \mathrm{~cm}$ for men $(28,29)$. These large differences within Mexico reflect the country's broad ethnic diversity (Additional File 2).

\section{Indigenous condition}

There are indigenous populations in all the states of the country, but with that prevalence differing from state to state. We analyzed the association between the prevalence of SS and the prevalence of indigenous language speakers (a feature considered a marker for the indigenous component). We found a positive association between them $\left(r_{s}=0.88\right.$, $p<0.001)$. This could suggest a confounding effect in the analysis. However, the trends in the prevalence of SS and the variables studied maintain their direction between categories when the analysis is carried out with adjustment for the prevalence of the indigenous component by state.

\section{DISCUSSION}

The objective of this population-based study was to estimate the associations between stature in Mexican adults and some sociodemographic factors.

As far as we know, this is the first study done for a Latin American country that identifies sociodemographic factors associated with stature by using a population-based analysis. We analyzed the data using -2 SDs, the $5^{\text {th }}$ percentile, and Q1 (25 $5^{\text {th }}$ percentile) as cutoffs, and found that the trend for the results did not change.

As we mentioned earlier, there are no established international cutoffs to define SS in adults. We used the Q1 because it allows comparisons between different populations and within the same population over time. Our results about cutoffs ( $\leq 148$ and $\leq 161 \mathrm{~cm}$ for women and men, respectively) are close to the cutoffs used previously by Vargas-Ancona ( $\leq 151$ and $\leq 164 \mathrm{~cm}$ for women and men, respectively) and Lara-Esqueda ( $\leq 150$ and $\leq 160 \mathrm{~cm}$ for women and men, respectively). However, the prevalences of SS by sex that we found in our study differ from the ones found by VargasAncona $(76.4 \%$ for women and $58.4 \%$ for men) and by Lara-Esqueda (25.8\% for women and $13.6 \%$ for men). Our design and study population could explain these differences.

We found some social inequalities related to stature in adults. When we compared the prevalence of SS by age group, older people had a higher prevalence of SS. This is in line with previous research (30). The prevalence of SS could be overestimated in this study as a consequence of the process of decreased mineral bone density due to aging, even though the population we studied was less than 60 years old.

Some authors who have conducted multicenter studies that analyze the evolution of adult stature in Europe have reported a gradual increase in adult height in all countries (31). Unfortunately, in Mexico there is no previous data that allow comparisons over time. Also, with the cross-sectional data in this

FIGURE 3. Prevalence of short stature ${ }^{a}$ in adults in Mexico City and the states of

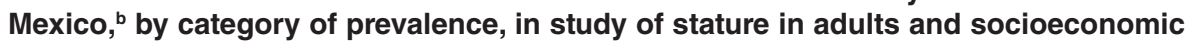
inequalities in Mexico

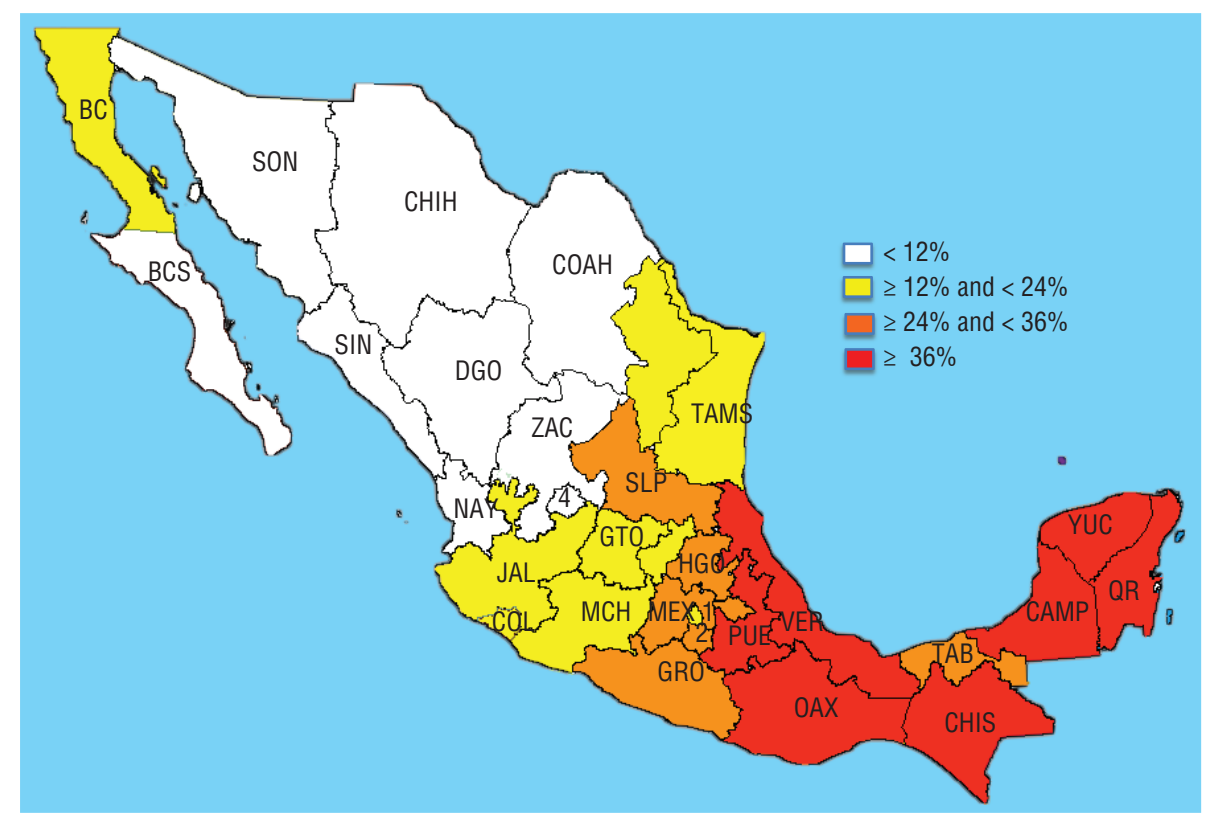

Source: Prepared by the authors based on data from 2012 National Health and Nutrition Survey (ENSANUT 2012). a Short stature is $\leq 148.5 \mathrm{~cm}$ for women and $\leq 161.1 \mathrm{~cm}$ for men.

${ }^{b}$ Mexico City and the states of Mexico are indicated in the map by either a number or an abbreviation. The four numbered locations are: 1, Mexico City; 2, Morelos; 3, Tlaxcala; and 4, Aguascalientes. The remaining states are: BC, Baja California; BCS, Baja California Sur; CAMP, Campeche; COAH, Coahuila; COL, Colima; CHIS, Chiapas; CHIH, Chihuahua; DUR, Durango; GTO, Guanajuato; GRO, Guerrero; HGO, Hidalgo; JAL, Jalisco; MEX, México; MICH, Michoacán; NAY, Nayarit; NL, Nuevo León; OAX, Oaxaca; PUE, Puebla; QRO, Querétaro; QR, Quintana Roo; SLP, San Luis Potosí; SIN, Sinaloa; SON, Sonora; TAB, Tabasco; TAMS, Tamaulipas; VER, Veracruz; YUC, Yucatán; and ZAC, Zacatecas. 
economic quintiles were taller than those who were in the poorest quintiles.

The Wronka study (32) concluded that socioeconomic status was related to body height, and that variation in height was the result of the living conditions during the first years of life. In contrast, Singh et al. (23) found a weak association between income and stature, but the association could be modified by the effect of education.

Our results suggest that SS in the Mexican population is largely associated with factors related to educational opportunities. This finding is consistent with some prior studies. For example, Garcia et al. (31) showed that taller people tend to reach higher levels of education; Singh et al. (23) found a positive association between schooling and income in relation to stature; and Cavelaar et al. (33) found that individuals with less schooling were, on average, shorter than persons with more schooling. However, other studies have reported different results for the association between schooling and stature. Castaño et al. (4) did not find a relation between education and stature in Colombians. The Wyshak study (34) did not find a significant association between stature and income or education in a group of women between 49 and 79 years old in the United States.

We found a higher prevalence of SS in the stratum with the highest marginalization. This result suggests that SS individuals may have fewer opportunities to get better jobs. This association might have derived from other confounding variables that would generate fewer employment opportunities, as reported by Case and Paxon (15). Those researchers attribute the link between stature and income to the positive association between stature and cognitive capacity, although it is cognitive ability rather than height that is rewarded in the job market. The positive association between height and intelligence quotient (IQ) has also been documented (15).

Our SS prevalence results by SES, region, and locality were the opposite of obesity prevalence results reported in a study by Barquera et al. (35). Both studies used the same ENSANUT 2012 data. In our analysis by geographic region, the northern region had the lowest prevalence of SS (12.2\%) but also the highest prevalence of obesity (37.3\%). Urban areas showed the highest prevalence of obesity but conversely the lowest prevalence of SS. Furthermore, people with the lowest socioeconomic status and the least schooling had the lowest obesity prevalence, but the highest prevalence of SS. When we compare the prevalence of obesity by schooling categories, we found a difference of less than 7 percentage points between the highest prevalence and the lowest one. On the other hand, when we compare the prevalence of SS, we found more than 40 percentage points of difference between the highest and the lowest prevalence.

In SS populations, using BMI to diagnose obesity must be reevaluated (9), since stature may change the relationship between BMI and adiposity.

We found that 8 of the 10 states with the highest prevalence of SS in our research were below the average of abdominal obesity reported in the study by Barquera et al. (35). These results could strongly support proposals for modifying the cutoffs to determine obesity in Mexican adults with SS $(9,11)$ or for using other adiposity assessment methods.

We found an overlap between the states with the highest percentage of indigenous language speakers and the states with the highest prevalence of SS. The four states with the highest prevalence of SS (Yucatan (58\%), Oaxaca (48\%), Chiapas (48\%), and Quintana Roo (44\%)) are the same four states that have the highest percentage of indigenous language speakers: Oaxaca (32\%), Yucatan (29\%), Chiapas (28\%), Quintana Roo $(17 \%)$, Guerrero $(15 \%)$, and Hidalgo (14\%) (21). However, when adjusting the data for this variable, the direction of inequality between the categories of the studied variables remained.

The association between the prevalence of SS and geographical location (higher prevalence in the south than in the north) could be partially explained by the multiracial populations that have resulted from the intermixing of indigenous groups with colonizing groups.

\section{Limitations}

In order to avoid a confounding effect from race, we used the prevalence of indigenous language speakers as a proxy for this variable. However, this component was analyzed using state-level data, not individual-level information. In addition, these data about ethnicity or race came from a source other than ENSANUT 2012.

The associations between stature and sociodemographic factors could have been confounded by variables that we did not consider or by imperfect measurement of the confounders that were included in our analysis.

Furthermore, because of the cross-sectional design of the study, the secular trend in stature cannot be estimated, and causal inferences from our analysis cannot be made with certainty.

\section{Conclusions}

We found a higher prevalence of SS in more vulnerable groups: those with lower socioeconomic status, less schooling, and greater marginalization.

The genetic component plays an essential role in the presence of SS. Therefore, longitudinal studies are warranted in order to determine the association between stature and opportunities for education, health, and employment, as well as the trend in average stature both regionally and countrywide.

From this analysis, it is possible to consider stature as an inequality indicator mainly in regions with the highest prevalence of SS.

Moreover, this work underscores the ethnic diversity in Mexico, through the variability in population stature, and it suggests the possibility of establishing regional cutoffs for SS.

Further studies are needed to explore if similar associations are observed in other Latin American populations.

Acknowledgments. We recognize the Academic Writing Team of the Centro de Estudios de Posgrado of UNAM for their help with this manuscript.

\section{Conflict of interests: None declared.}

Disclaimer. Authors hold sole responsibility for the views expressed in the manuscript, which may not necessarily reflect the opinion or policy of the RPSP/ PAJPH or PAHO. 


\section{REFERENCES}

1. Subramanian S, Özaltin E, Finlay JE. Height of nations: a socioeconomic analysis of cohort differences and patterns among women in 54 low to middle income countries. PLoS One. 2011 Apr;6(4):1-13.

2. Dauber A, Yu Y, Turchin MC, Chiang CW, Meng YA, Demerath EW, et al. Genomewide association of copy-number variation reveals an association between short stature and the presence of low-frequency genomic deletions. Am J Med Genet. 2011 Dec 9;89:751-9.

3. Steckel RH. Heights and human welfare: recent developments and new directions. Explor Econ Hist. 2009 Jan 31;46(1):1-23.

4. Castaño LSA, Restrepo AE, Rueda JDG, Aguirre CC, López LPM. The effects of socioeconomic status and short stature on overweight, obesity and the risk of metabolic complications in adults. Colomb Med. 2013 Sep 3;44(3):146-54.

5. Bramswig JH. Estatura baja y estatura alta. Ann Nestlé (Ed española). 2007;65:119-29.

6. Lee EM, Park MJ, Ahn HS, Lee SM. Differences in dietary intakes between normal and short stature Korean children visiting a growth clinic. Clin Nutr Res. 2012 Jul 26;1:23-9.

7. Silventoinen K. Determinants of variation in adult body height. J Biosoc Sci. 2003 Apr;35(2):263-85.

8. Vargas-Ancona L. Epidemiología de la diabetes mellitus, intolerancia a la glucosa y factores de riesgo aterogénico en Yucatán, México. Rev Biomed. 1994 Jul 29;5(3):151-9.

9. López-Alvarenga JC, Montesinos-Cabrera RA, Velázquez-Alva C, González-Barranco J. Short stature is related to high body fat composition despite body mass index in a Mexican population. Arch Med Res. 2003 Mar-Apr;34(2):137-40.

10. Lara-Esqueda A, Aguilar-Salinas CA, Velazquez-Monroy O, Gómez-Pérez FJ, Rosas-Peralta M, Mehta R, et al. The body mass index is a less-sensitive tool for detecting cases with obesity-associated co-morbidities in short stature subjects. Int J Obes Relat Metab Disord. 2004 Nov;28: 1443-50.

11. Estados Unidos Mexicanos, Secretaría de Salud. NORMA Oficial Mexicana NOM008-SSA3-2010, Para el tratamiento integral del sobrepeso y la obesidad. Diario Oficial de la Federación. 2010 Aug 4; (Primera Sección):1-10.

12. Bosy-Westphal A, Plachta-Danielzik S, Dörhöfer R-P, Müller MJ. Short stature and obesity: positive association in adults but inverse association in children and adolescents. Br J Nutr. 2009 Aug;102(3):453-61.
13. Oyesiku L, Solomons NW, Doak CM, Vossenaar M. Highland Guatemalan women are extremely short of stature, and no lactation duration effects on body composition are observed in a cross-sectional survey. Nutr Res. 2013 Feb;33(2):87-94.

14. Sichieri R, Dos Santos Barbosa F, Moura EC. Relationship between short stature and obesity in Brazil: a multilevel analysis. Br J Nutr. 2010 May;103(10):1534-8.

15. Case A, Paxson C. Stature and status: height, ability, and labor market outcomes. J Polit Econ. 2008;116(3):499-532.

16. Florêncio TT, Ferreira HS, Cavalcante JC, Sawaya AL. Short stature, obesity and arterial hypertension in a very low income population in North-eastern Brazil. Nutr Metab Cardiovasc Dis. 2004 Feb;14(1):26-33.

17. Hoque M, Erfanul M, Rahman K, Bari W. Impact of stature on non-communicable diseases: evidence based on Bangladesh Demographic and Health Survey, 2011 data. BMC Public Health. 2014 Sep 26;14:1007.

18. Miedema MD, Petrone AB, Arnett DK, Dodson JA, Carr JJ, Pankow JS, et al. Adult height and prevalence of coronary artery calcium: The NHLBI Family Heart Study. Circ Cardiovasc Imaging. 2014 Jan;7(1): 52-7.

19. Sichieri R, Siqueira KS, Pereira RA, Ascherio A. Short stature and hypertension in the city of Rio de Janeiro, Brazil. Public Health Nutr. 2000 Mar;3(1):77-82.

20. Wadén J, Forsblom C, Thorn LM, Saraheimo $M$, Rosengård-Bärlund $M$, Heikkilä $\mathrm{O}$, et al. Adult stature and diabetes complications in patients with type 1 diabetes: the FinnDiane Study and the Diabetes Control and Complications Trial. Diabetes. 2009 Aug;58(8):1914-20.

21. Instituto Nacional de Estadística y Geografía. Principales resultados de la Encuesta Intercensal 2015. Aguascalientes, México: INEGI; 2015.

22. Tyrrell J, Jones SE, Beaumont R, Astley CM, Lovell R, Yaghootkar H, et al. Height, body mass index, and socioeconomic status: mendelian randomisation study in UK Biobank. BMJ. 2016 Mar 8;352:i582.

23. Singh-Manoux A, Gourmelen J, Ferrie J, Silventoinen K, Guéguen A, Stringhini S, et al. Trends in the association between height and socioeconomic indicators in France, 1970-2003. Econ Hum Biol. 2010 Dec;8(3):396-404.

24. Schick A, Steckel RH. Height, human capital, and earnings: the contributions of cognitive and noncognitive ability. J Hum Cap. 2015;9(1):94-115.
25. Instituto Nacional de Estadística y Geografía. Encuesta Intercensal 2015 Síntesis metodológica y conceptual. Aguascalientes, México: INEGI; 2015.

26. Romero-Martínez M, Shamah-Levy $T$, Franco-Núñez A, Villalpando S, CuevasNasu L, Gutiérrez JP, et al. Encuesta Nacional de Salud y Nutrición 2012: diseño y cobertura. Salud Publica Mex. 2013;55:S332-40.

27. Gutiérrez JP. Household socioeconomic classification in the National Health and Nutrition Survey 2012. Salud Publica Mex. 2013;55 Suppl 2(1):S341-6.

28. Fryar CD, Gu Q, Ogden CL. Anthropometric reference data for children and adults: United States, 2007-2010. Vital Health Stat. 2012 Oct;11(252):1-48.

29. McDowell M, Fryar C, Ogden C, Flegal K. Anthropometric reference data for children and adults: United States, 2003-2006. Natl Health Stat Report. 2008 Oct 22;(10):1-48.

30. Sorkin JD, Muller DC, Andres R. Longitudinal change in height of men and women: implications for interpretation of the body mass index: the Baltimore Longitudinal Study of Aging. Am J Epidemiol. 1999 Nov 1;150(9):969-77.

31. Garcia J, Quintana-Domeque C. The evolution of adult height in Europe: a brief note. Econ Hum Biol. 2007 Jul;5(2): 340-9.

32. Wronka I. Body height and socioeconomic status of females at different life stages. J Biosoc Sci. 2013 Jul;45(4):471-80.

33. Cavelaars AE, Kunts AE, Geurts JJ, Crialesi L, Grotvedt R, Helmert E, et al. Persistent variations in average height between countries and between socio-economic groups: an overview of 10 European countries. Ann Hum Biol. 2000 Jul-Aug;27(4): 407-21.

34. Wyshak G. Height, socioeconomic and subjective well-being factors among U.S. women, ages 49-79. PLoS One. 2014 Jun 4;9(6):e96061.

35. Barquera S, Campos-Nonato I, HernándezBarrera L, Pedroza-Tobías A, RiveraDommarco JA. Prevalencia de obesidad en adultos mexicanos, ENSANUT 2012. Salud Publica Mex. 2013;55:151-60.

Manuscript received on 4 May 2017. Revised version accepted for publication on 8 September 2017. 
RESUMEN Objetivo. Establecer la asociación entre la estatura de los mexicanos adultos y algunos factores sociodemográficos.

Métodos. Sobre la base de datos antropométricos de la Encuesta Nacional de Salud

La estatura de los adultos como indicador de las desigualdades socioeconómicas en México

Palabras clave Factores socioeconómicos; estatura; adulto; población indígena; México. y Nutrición de 2012 (ENSANUT 2012), estudiamos una muestra de 30970 sujetos. Para definir la estatura baja, el umbral se estableció en el primer cuartil. Analizamos las diferencias entre los distintos estratos de estatura en relación con variables sociodemográficas utilizando la prueba de Kruskal-Wallis. Calculamos las razones de posibilidades para medir la asociación entre la estatura y las variables sociodemográficas, con control de posibles factores de confusión.

Resultados. Las personas de la zona meridional del país tenían alrededor de tres veces más probabilidades de ser de estatura baja que las personas de la zona septentrional. La diferencia entre los estados mexicanos con la estatura promedio más alta y la estatura promedio más baja fue mayor que la diferencia promedio respecto de la estatura entre México y los Estados Unidos de América. La prevalencia más alta de estatura baja se registró en los adultos con menos de seis años de escolaridad, independientemente del sexo, la zona del país, el lugar de residencia (rural o urbano) y la proporción de hablantes de lenguas indígenas en un estado. Además, la prevalencia más alta de estatura baja se observó en el estrato de población más marginada (porcentaje de habitantes sin escolaridad ni servicios, con ingresos bajos y que vivían una comunidad pequeña).

Conclusiones. En México, las condiciones de vida de los adultos de estatura baja son más desfavorables que las de los adultos de estatura media o alta, y esto podría contribuir a aumentar la inequidad en materia de salud.

RESUMO Objetivo. Estimar a associação entre a estatura em adultos mexicanos e fatores sociodemográficos.

Métodos. Foi estudada uma amostra de 30.970 indivíduos com base em dados antropométricos obtidos da Pesquisa Nacional sobre Saúde e Nutrição de 2012 (ENSANUT

Estatura em adultos como indicador das desigualdades socioeconômicas no México

Palavras-chave
2012). O primeiro quartil foi usado como valor de corte para definir baixa estatura. Foram analisadas as diferenças entre os estratos de estatura para as variáveis sociodemográficas com o uso do teste de Kruskal- Wallis. Foram estimados os odds ratios para medir a associação entre a estatura e as variáveis sociodemográficas, controlando-se os potenciais fatores de confusão.

Resultados. Os indivíduos da região sul do país apresentaram uma chance quase três vezes maior de ter baixa estatura em comparação aos indivíduos da região norte. A diferença de estatura entre os estados mexicanos com a estatura média maior e a estatura média menor foi maior que a diferença média em estatura entre o México e os Estados Unidos. Os adultos com menos de seis anos de escolaridade apresentaram a prevalência mais elevada de baixa estatura, independentemente do sexo, região do país, zona de residência (rural ou urbana) ou proporção de falantes de línguas indígenas em um estado. Além disso, o estrato com maior marginação (porcentagem de habitantes com carência de educação e serviços, de baixa renda e vivendo em uma pequena comunidade) apresentou a prevalência mais elevada de baixa estatura. Conclusão. No México, os adultos com baixa estatura têm condições de vida desiguais comparados aos adultos com estatura média ou alta, contribuindo para maior iniquidade em saúde.

Fatores socioeconômicos; estatura; adulto; população indígena; México. 